\section{Prakhar Kumar Kharwar}

Research Schola Madan Mohan Malaviya Univeristy of Technology, Gorakhpur Department of Mechanical Engineering

Rajesh Kumar Verma Associate Professor Madan Mohan Malaviya Univeristy of Technology, Gorakhpur Department of Mechanical Engineering

\title{
Grey Embedded in Artificial Neural Network (ANN) Based on Hybrid Optimization Approach in Machining of GFRP Epoxy Composites
}

Glass fibre reinforced epoxy polymers (GFRP) composites have gathered enormous attraction because of their exceptional engineering properties such as superior proportion in strength-to-weight and enhanced durability. However, to develop a machined component is a difficult task due to nonhomogeneity and anisotropic behavior of GFRP. In this study a hybrid module, Grey relational analysis (GRA) embedded in artificial neural network (ANN) based on Taguchi approach for multicriteria optimization in Turning of GFRP materials has been carried out. The desired machining characteristics are minimum cutting force, minimum surface roughness \& maximum rate of material removal \& these have been used to calculate the Grey relational coefficient for individual response and then converted into the single response function i.e. Grey relational grade (GRG) value which was used for converting multiobjective problem into single objective problem and then well-trained ANN based on the Levenberg-Marquardt Back Propagation (LMBP) algorithm has been used to predict the most favourable process parameters setting i.e. spindle speed (880 rpm), feed rate $(0.05 \mathrm{~mm} / \mathrm{rev}$.), depth of cut $(0.4 \mathrm{~mm})$. The predicted $G R G$ of process parameters via $L_{16} O A$ of Taguchi-based GRA with ANN has been improved by $8.5 \%$.This setting has been selected based on highest GRG predicted by well-trained ANN which finally has been checked by the confirmatory test which produces satisfactory results.

Keywords : GRG; ANN; GRA;GFRP;Taguchi, etc.

\section{INTRODUCTION}

GFRP are modern category of polymer matrix composite materials which show superordinate stiffness and strength to weight ratio. Therefore, rapidly achieved prominent place in automotive, aerospace and other new technology demanding industries, in which weight and performance are primary design constraints. Literature depicts that very limited amount of work has been carried out by a pioneer researcher to explore the different aspects in machinability and machining performance of GFRP composites. In industries, the rate of material removal and surface integrities play an important role for quality and productivity characteristics. The credibility for GFRP machined components, particularly for strength application generally depends upon surface reliability which may drastically affect chemical resistance and strength of materials. In this context, it is important to study the parametric appraisal during machining of these polymeric materials. There should be a companionable equilibrium between quality and production rate in case of machining of GFRP composites.

Received: November 2018, Accepted: March 2019

Correspondence to: Dr. Rajesh Kumar Verma

Department of Mechanical Engineering, Madan Mohan

Malaviya University of Technology, Gorakhpur, India

E-mail: rajeshverma.nit@gmail.com

doi: $\mathbf{1 0 . 5 9 3 7 / f m e t 1 9 0 3 6 4 1 P}$

(C) Faculty of Mechanical Engineering, Belgrade. All rights reserved

\subsection{Previous work}

Uhlmann et al.[1] used carbon and glass fibre reinforced composites and performed machining on these materials and analysed the fibre pull-out and fibre protrusion during the machining and found that poor quality hole with high value of fibre pullout with the glass fibres than carbon fibre and CVD coated diamond have not deliver any benefit during drilling operation due to higher cutting edge passing of the tool. Zitoune et al.[2] conducted and experiment on unidirectional carbon reinforced epoxy laminated composites in which orthogonal cutting applied for various angles between cutting tool and fibre direction and second interest with numerical modelling of cutting for the case of fibre direction and methods of cutting frequency of the tool along the chip creation as well as the separation modes. Verma et al. [3,12] examined the effect of input variable using fuzzy logic for enhancing the rate of materials removal and minimizing the roughness of surface during turning operation of GFRP composites. This study developed a relativily novel fuzzy based taguchi approach for machining of GFRP and equate this module with WPCA and PCA based Taguchi component. Khan et al. [4] generate mathematical model for machining of polymer composites which is reinforced by glass fibre with $\mathrm{Ti}$ [C, N] blended alumina-based ceramic cutting tool (CC650) and Si-C whisker strengthened tool (CC670) 
for adjusting the element manufacture rate. Kumar et al. [5] examined two distinguished developmental procedure constructed neural structure namely genetic algorithm based neural network (GA-NN) \& particle swarm optimization constructed neural network (PSO$\mathrm{NN}$ ). It has been discovered from works that a lesser amount of variety of effort has been there to find favourable machining condition by using evolutionary metaheuristics modules. Most commonly, genetic algorithm is applied for optimization of parametric setting in machining and machinability of polymeric materials. Ramulu [6] optimized the wear rate of tool, material removal rate and roughness of surface in EDM of aluminium diboride which is reinforced with aluminium reinforced LM25 functionally graded composites. Agarwal et al. [7] developed a hybrid (GRA-ANN) model to predict optimal setting of Electrochemical machining(ECM) parameters with highest GRG value for Material removal rate, under cut and Etch factor. The ANN component also delivers the acceptable performance for trends investigation for specified set of tests. In this study a suface curve is a plot which represents the machining characterictis in a better way. Lakshminarayanan et al. [8] used Taguchi based L9 orthogonal arrangement (OA) and analysis of variance (ANOVA) test to classify the important factor which alters the strength of friction stir welded RDE-40 Al alloy joints. Taguchi's philosophy had limitation to solve multi-optimization problem which can be overcome by converting multi-objective problem into single response by using Grey Relational Analysis (GRA). Ezugwu et al. [13] developed ANN models for modeling the correlation between cutting and process parameters in high-speed machining of Inconel 718 alloy. In order to determine the optimal ANN architecture, single and double hidden layer networks with 10 and 15 hidden neurons were considered. The networks were trained with Levenberg-Marquardt (LM) algorithm with Bayesian regularization and early stopping procedure. Hans Ray et al. [14] showed some advantages of training ANNs using LM algorithm over the standard backpropagation (BP) algorithm in modeling of metal forming and metal cutting processes. They used double hidden layers ANNs with equal number of neurons in both hidden layers. The results obtained are found to correlate well with the finite element simulation data in cases of metal forming, and experimental data in case of metal cutting. Zain et al. [15] applied ANNs for developing the prediction model for surface roughness in the end milling. Three cutting parameters (cutting speed, feed rate and rake angle) were considered as ANN inputs. The determination of the number of layers and neurons in the hidden layers is done by the trial-and-error method considering some guidelines from literature.

Literature depicts that efforts have been made by previous pioneer researchers in understanding the machining behaviour of polymer materials. Machinability aspects with a variety of tool-work material combination have been addressed and well documented in literature. Predictive models have also been developed using regression modelling, response surface modelling as well as neural network. However, it has been found that optimization characteristics have also been tried; but to a restricted level. However, application of traditional Taguchi based optimization methodologies seems not enough reliable as these approaches assume individual response priority weights depending on the observation of decision-makers. This could generate ambiguity \& inaccuracy in the optimal setting selection. To avoid the limitation of traditional Taguchi method, Grey relational analysis (GRA) concept embedded with artificial neural network (ANN) based Taguchi approach for multi criteria optimization has been applied to simultaneously optimize the cutting force surface roughness and rate of Material Removal (MRR in machining (turning) of glass fibre reinforced (epoxy) composites.

\section{EXPERIMENT DETAILS}

In this study three process parameters have been selected, experiment performed on manual operated lathe [PINACHO]. Turning specimen is prepared with $23 \%$ glass fibre and remaining is epoxy $(77 \%)$ with $0^{\circ}$ and $90^{\circ}$ fibre orientations. To conduct the experiments depth of cut, feed rate and spindle speed were considered as input parameters with Four level shown in table 1 .

Table 1. Process parameters

\begin{tabular}{|c|c|c|c|}
\hline \multirow{3}{*}{$\begin{array}{c}\text { Level of } \\
\text { Input } \\
\text { Parameters }\end{array}$} & \multicolumn{3}{|c|}{ Input Parameters } \\
\hline & $\begin{array}{c}\text { Spindle Speed } \\
\text { (N) }\end{array}$ & $\begin{array}{l}\text { Feed rate } \\
\text { (f) }\end{array}$ & $\begin{array}{l}\text { Depth of } \\
\text { cut }(d)\end{array}$ \\
\hline & (RPM) & $(\mathrm{mm} / \mathrm{rev})$ & $(\mathrm{mm})$ \\
\hline 1 & 220 & 0.06 & 0.6 \\
\hline 2 & 360 & 0.066 & 0.8 \\
\hline 3 & 530 & 0.72 & 1 \\
\hline 4 & 860 & 0.077 & 1.2 \\
\hline
\end{tabular}

Table 2. Design of Experiment (DOE) and Experimental data

\begin{tabular}{|c|c|c|c|c|c|c|}
\hline $\begin{array}{c}\text { Exp. } \\
\text { No. }\end{array}$ & $\begin{array}{c}\text { Spindle } \\
\text { Speed } \\
\text { N } \\
{[\mathrm{RPM}]}\end{array}$ & $\begin{array}{c}\text { Feed rate } \\
\text { F } \\
{[\mathrm{mm} / \mathrm{rev}]}\end{array}$ & $\begin{array}{c}\text { Depth } \\
\text { of cut } \\
\mathrm{D} \\
{[\mathrm{mm}]}\end{array}$ & $\begin{array}{c}\mathrm{Fr} \\
\mathrm{kN}\end{array}$ & $\begin{array}{c}\mathrm{Ra} \\
\mu \mathrm{m}\end{array}$ & $\begin{array}{c}\text { MRR } \\
\mathrm{mm} 3 / \mathrm{min}\end{array}$ \\
\hline 1 & 220 & 0.060 & 0.6 & 38.5369 & 12.0613 & 1571.856 \\
\hline 2 & 220 & 0.066 & 0.8 & 48.3727 & 15.9563 & 1497.006 \\
\hline 3 & 220 & 0.072 & 1 & 68.3287 & 9.76066 & 2365.269 \\
\hline 4 & 220 & 0.077 & 1.2 & 64.8527 & 17.1276 & 3368.263 \\
\hline 5 & 360 & 0.060 & 0.8 & 26.7490 & 18.4423 & 1197.605 \\
\hline 6 & 360 & 0.066 & 0.6 & 29.5188 & 20.2216 & 1137.725 \\
\hline 7 & 360 & 0.072 & 1.2 & 46.4334 & 24.0876 & 2245.509 \\
\hline 8 & 360 & 0.077 & 1 & 46.8114 & 11.7740 & 2035.928 \\
\hline 9 & 530 & 0.060 & 1 & 48.4970 & 12.6080 & 1586.826 \\
\hline 10 & 530 & 0.066 & 1.2 & 40.1330 & 21.2756 & 2994.012 \\
\hline 11 & 530 & 0.072 & 0.6 & 24.7738 & 21.5373 & 2994.012 \\
\hline 12 & 530 & 0.077 & 0.8 & 36.0519 & 21.4543 & 4491.018 \\
\hline 13 & 860 & 0.060 & 1.2 & 45.9710 & 13.4570 & 5014.97 \\
\hline 14 & 860 & 0.066 & 1 & 39.1064 & 11.0876 & 3532.934 \\
\hline 15 & 860 & 0.072 & 0.8 & 40.7971 & 12.99967 & 4491.018 \\
\hline 16 & 860 & 0.077 & 0.6 & 39.0403 & 15.3933 & 4358.458 \\
\hline
\end{tabular}

This study considers three process parameters, so Taguchi's methodology has been used to construct the experiment design. $A \mathrm{~L}_{16} \mathrm{OA}$ has been chosen for experiment. In this study, the performance of machining parameters has been evaluated in terms of resultant cutt- 
Table 3. Normalized Response Values for Conducted Experiments

\begin{tabular}{|l|l|l|l|l|l|l|}
\hline \multirow{2}{*}{$\begin{array}{l}\text { EXP. } \\
\text { No. }\end{array}$} & \multicolumn{4}{|c|}{ Experimental Data } & \multicolumn{3}{|l|}{ Normalized Experimental data } \\
\cline { 2 - 7 } & $\begin{array}{l}\text { Fr } \\
{[\mathrm{kN}]}\end{array}$ & $\begin{array}{l}\text { Ra } \\
{[\mu \mathrm{m}]}\end{array}$ & $\begin{array}{l}\text { MRR } \\
{\left[\mathrm{mm}^{3} / \mathrm{min}\right]}\end{array}$ & Fr & MRR \\
\hline 1 & 38.5369 & 12.0613 & 1571.856 & 0.684005703 & 0.839418606 & 0.111968937 \\
\hline 2 & 48.3727 & 15.9563 & 1497.006 & 0.458180365 & 0.567553155 & 0.092663992 \\
\hline 3 & 68.3287 & 9.76066 & 2365.269 & 0 & 1 & 0.316602123 \\
\hline 4 & 64.8527 & 17.1276 & 3368.263 & 0.079807324 & 0.485798084 & 0.575289413 \\
\hline 5 & 26.7490 & 18.4423 & 1197.605 & 0.954650338 & 0.394033897 & 0.015443956 \\
\hline 6 & 29.5188 & 20.2216 & 1137.725 & 0.891057034 & 0.269841292 & 0 \\
\hline 7 & 46.4334 & 24.0876 & 2245.509 & 0.502705781 & 0 & 0.285714212 \\
\hline 8 & 46.8114 & 11.7740 & 2035.928 & 0.494027078 & 0.859471736 & 0.231660109 \\
\hline 9 & 48.4970 & 12.6080 & 1586.826 & 0.455326496 & 0.801259725 & 0.115829926 \\
\hline 10 & 40.1330 & 21.2756 & 2994.012 & 0.647359999 & 0.196273594 & 0.478764432 \\
\hline 11 & 24.7738 & 21.5373 & 2994.012 & 1 & 0.178007307 & 0.478764432 \\
\hline 12 & 36.0519 & 21.4543 & 4491.018 & 0.741060133 & 0.183800588 & 0.864864872 \\
\hline 13 & 45.9710 & 13.4570 & 5014.97 & 0.513322267 & 0.742000734 & \\
\hline 14 & 39.1064 & 11.0876 & 3532.934 & 0.670930251 & 0.907381479 & 0.617760549 \\
\hline 15 & 40.7971 & 12.99967 & 4491.018 & 0.632112575 & 0.773921717 & 0.864864872 \\
\hline 16 & 39.0403 & 15.3933 & 4358.458 & 0.672447876 & 0.606849753 & 0.830675647 \\
\hline
\end{tabular}

ing force, surface roughness and rate of material removal shown in Table 2. Rate of Material removal is explained by volumetric quantity of material removed during machining with respect to machining time.

$$
M R R=\frac{\left(W_{1}-W_{2}\right)}{\rho \cdot t_{m}} \frac{\mathrm{mm}^{3}}{\min }
$$

$\mathrm{W}_{1}$ and $\mathrm{W}_{2}$ is initial and final weight of specimen and $\rho$ is density of specimen and $t_{m}$ is time required for machining of specimen.SJ-210 (manufacturer: Mitutoyo) is used for measurement of surface roughness, and for measurement of cutting force in all three direction $\left(\mathrm{F}_{X}\right.$, $\mathrm{F}_{\mathrm{Y}}$ and $\mathrm{F}_{\mathrm{Z}}$ ) lathe tool dynamometer (manufacturer: MEDILAB ENETRPRISES) is used and resultant cutting force $(\mathrm{Fr})$ is calculated with the help of equation (2):

$$
F_{r}=\sqrt{F_{x}^{2}+F_{y}^{2}+F_{z}^{2}}
$$

\section{GREY RELATIONAL ANALYSIS}

Grey Relational Analysis (GRA) are normalization evolution Techniques which are mainly used for multiple performance characteristic optimizations.

GRA method consists of following steps:

1) Conduction of experiment at settings of parameters according to Taguchi orthogonal array

2) Normalization of experimental results

3) Determination of GRC

4) Calculation of Grey relational Grade (GRG) and their corresponding rank

5) Selection of optimal process parameters. Multiple outcome of experiment was investigated using GRA. GRA approaches allows multiple response such material removal, cutting force and surface roughness being converted into single grey relational grade (GRG) [9].

\subsection{Data Normalization}

Firstly, all the experimental data (Table 2) retrieved were normalized in the series of 0 to 1 using equation no. $3 \& 4$. These machining characteristics are characterized, where lower the better (LB) characteristic is desired for cutting force and surface roughness and higher the better (HB) characteristic is desired for rate of material removal. The following equations were used to normalize the experimental data [10].

$$
x_{i}^{*}(j)=\frac{x_{i}(j)-\min x_{i}(j)}{\max x_{i}(j)-\min x_{i}(j)}
$$

higher-the-better

$$
x_{i}^{*}(j)=\frac{\min x_{i}(j)-x_{i}(j)}{\max x_{i}(j)-\min x_{i}(j)}
$$

lower-the-better

where $x_{i}(j)$ is comparability sequence and $x_{i}^{*}(j)$ sequence afterward data pre-processing. Table 3 illustrates the normalized sequence aimed at all the responses founded on their corresponding performance characteristics.

\subsection{Derivation Sequences}

$\Delta_{o i}(j)$ deviation sequence of the reference sequence $x_{o}{ }^{*}$ $(j)$ and the comparability sequence $x_{i}^{*}(j)$ as shown in table 4:

$$
\Delta_{o i}(k)=\left|\varkappa_{i}^{*}(j)-x_{i}^{*}(j)\right|
$$

The deviation sequences were determined and summarized in Table 4.

Table 4. Deviation Sequence

\begin{tabular}{|c|c|c|c|}
\hline $\begin{array}{c}\text { Deviation } \\
\text { Sequence }\end{array}$ & $\Delta_{o i}(1)$ & $\Delta_{o i}(2)$ & $\Delta_{o i}(3)$ \\
\hline Exp. No. 1 & 0.315994297 & 0.160581394 & 0.888031063 \\
\hline Exp. No. 2 & 0.541819635 & 0.432446845 & 0.907336008 \\
\hline Exp. No. 3 & 1 & 0 & 0.683397877 \\
\hline Exp. No. 4 & 0.920192676 & 0.514201916 & 0.424710587 \\
\hline Exp. No. 5 & 0.045349662 & 0.605966103 & 0.984556044 \\
\hline Exp. No. 6 & 0.108942966 & 0.730158708 & 1 \\
\hline Exp. No. 7 & 0.497294219 & 1 & 0.714285788 \\
\hline Exp. No. 8 & 0.505972922 & 0.140528264 & 0.768339891 \\
\hline Exp. No.9 & 0.544673504 & 0.198740275 & 0.884170074 \\
\hline Exp. No. 10 & 0.352640001 & 0.803726406 & 0.521235568 \\
\hline Exp. No. 11 & 0 & 0.821992693 & 0.521235568 \\
\hline Exp. No. 12 & 0.258939867 & 0.816199412 & 0.135135128 \\
\hline Exp. No. 13 & 0.486677733 & 0.257999266 & 0 \\
\hline Exp. No. 14 & 0.329069749 & 0.092618521 & 0.382239451 \\
\hline Exp. No. 15 & 0.367887425 & 0.226078283 & 0.135135128 \\
\hline Exp. No. 16 & 0.327552124 & 0.393150247 & 0.169324353 \\
\hline
\end{tabular}




\subsection{Grey Relational Coefficient and Grade}

Subsequently, data normalization is completed, with the help of pre-processed sequence Grey relational coefficient (GRC) is calculated. The Grey Relational coefficient is defined in equation (6) [9]:

$$
\xi_{i}(k)=\frac{\Delta_{\min }+\xi \Delta_{\max }}{\Delta o i+\xi \Delta_{\max }}
$$

where $\xi$ is well-defined as an identification coefficient. In this work, all the process parameters were given equivalent preference by considering $\xi=0.5$, while $\Delta$ max. and $\Delta$ min. shows the maximum and minimum absolute variance. The GRG for each experiment were intended by collecting the mean values of the GRCs for MRR, Ra and Fr. The rank of respectively experiment was tabularized grounded on the highest GRG as listed in Table 5. The higher value of GRG is extremely desired for favorable parametric setting during multiattribute optimization.

\subsection{GRG for Process Parameter Levels.}

In Table 5, experiment row no. 13 shows the best multiple performance characteristic because this combination of machining process parameters has highest Grey Relational Grade (GRG) value. Since this experimental design is based on Taguchi OA so Grey relational grade can be separate out at different level. Here, GRG value for factor A depth of cut its $1^{\text {st }}$ level $(0.6 \mathrm{~m})$ can be determined by mean value of the corresponding GRG values at the experimentation sequence 1-4 as level 1 was allocated for factor A which is listed in table 2. The calculated GRG values for process parameters is listed in Table 5.
Fundamentally, the greater GRG represents the optimal setting of machining parameters. Figure 1 shows the most optimal process parameters value based on the highest GRG which are A4B1C1. The predicted Grey relational grade (GRG) of the optimal process parameters level for the experiment can be calculated using equation (7):

$$
\hat{\gamma}=\gamma_{m}+\sum_{i=1}^{n}\left(\gamma_{i}-\gamma_{m}\right)
$$

where $\gamma_{m}$ and $\gamma_{i}$ represent total mean of GRG and GRG mean at optimal level respectively, and $n$ is the total number consider process parameters. The predicted GRG is calculated as follows:

$$
\begin{aligned}
& \hat{\gamma}=0.56832+(0.67857-0.5682)+(0.59645-0.5682)+ \\
& +(0.58913-0.5682) \\
& \hat{\gamma}=0.72787
\end{aligned}
$$

- Level 1 Level 2 Level 3 Level 4

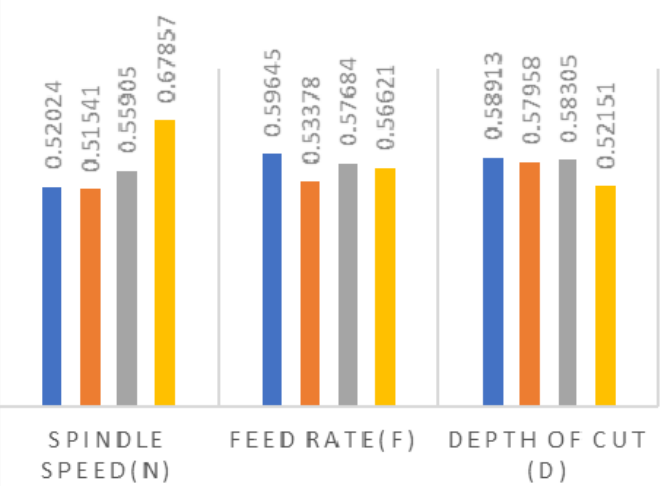

Figure 1. Factor effect plot of GRGs for Multiple Responses

Table 5. Determination of Grey Relation Coefficient and GRG values

\begin{tabular}{|l|l|l|l|l|l|}
\hline Exp. No. & \multicolumn{3}{|c|}{ GRC } & \multirow{2}{*}{ GRG } & \multirow{2}{*}{ Rank } \\
\hline & Fr, $\xi_{i}(1)$ & $R a, \xi_{i}(2)$ & MRR, $\xi_{i}(3)$ & & \\
\hline 1 & 0.612749381 & 0.756908996 & 0.36022249 & 0.57662 & 8 \\
\hline 2 & 0.479929523 & 0.536223596 & 0.35528118 & 0.45714 & 15 \\
\hline 3 & 0.333333333 & 1 & 0.42251217 & 0.58528 & 7 \\
\hline 4 & 0.352064905 & 0.492998477 & 0.54070972 & 0.46192 & 14 \\
\hline 5 & 0.916842963 & 0.452093422 & 0.33680103 & 0.56857 & 9 \\
\hline 6 & 0.821094959 & 0.40645162 & 0.33333333 & 0.52029 & 11 \\
\hline 7 & 0.501356561 & 0.333333333 & 0.41176468 & 0.41548 & 16 \\
\hline 8 & 0.497031271 & 0.780605679 & 0.3942161 & 0.55728 & 10 \\
\hline 9 & 0.478618437 & 0.715573465 & 0.36122729 & 0.51847 & 12 \\
\hline 10 & 0.58641396 & 0.383516049 & 0.489603 & 0.48651 & 13 \\
\hline 11 & 1 & 0.378216916 & 0.489603 & 0.62260 & 5 \\
\hline 12 & 0.658813724 & 0.379881647 & 0.78723405 & 0.60864 & 6 \\
\hline 13 & 0.506751073 & 0.659631246 & 1 & 0.72212 & 1 \\
\hline 14 & 0.603085568 & 0.843713083 & 0.56673956 & 0.67117 & 3 \\
\hline 15 & 0.576111585 & 0.68863098 & 0.78723405 & 0.68399 & 2 \\
\hline 16 & 0.604191549 & 0.559816225 & 0.74702198 & 0.63700 & 4 \\
\hline
\end{tabular}

Table 6. Average GRG by Process Parameter Levels

\begin{tabular}{|c|c|c|c|c|c|}
\hline \multirow{2}{*}{ Sym. } & Process & \multicolumn{4}{|c|}{ Grey Relation Grade } \\
\cline { 3 - 6 } & Parameters & Level 1 & Level 2 & Level 3 & Level 4 \\
\hline A & Spindle Speed (N) & 0.52024 & 0.51541 & 0.55905 & 0.67857 \\
\hline B & Feed rate (f) & 0.59645 & 0.53378 & 0.57684 & 0.56621 \\
\hline C & Depth of cut (d) & 0.58913 & 0.57958 & 0.58305 & 0.52151 \\
\hline
\end{tabular}




\section{OPTIMIZATION USING ARTIFICIAL NEURAL NETWORK}

ANN is used to model critical manufacturing process, typically process and quality control. The LMBP algorithm has been considered for modelling a well-trained Artificial Neural Network due to it faster training time [11]. LMBP algorithm provides non-linear dependency between process parameters and Grey Relation Grade. The LMBP algorithm is the fastest algorithm for training of multi-layer networks, despite of having a matrix inversion at each iteration. The development of a well-trained ANN was conducted using MATLAB application tools. Then, the multiple characteristics, cutting force, surface roughness and rate of material removal has been converted into sixteen GRGs. The combination of the process parameters based on sixteen experiments and the sixteen GRGs are fed into neural network to be trained. Based on the training, sixteen predicted GRGs are produced. The well-trained network will be the medium to tune the best process parameter that will result in the most optimum value for cutting force surface roughness and rate of materials removal.

\subsection{Training of Back Propagation Network}

Back propagation neural network is typical combination of input layers, one or more than one hidden layer and one output layers. In this paper, set of three inputs values which are spindle speed and feed rate and depth of cut and predicts one target value which is GRG.The transfer functions for all hidden neurons are set to be tangent sigmoid functions while the output neurons are set as a linear function. Figure 2 shows the topology of the network. Prediction outputs for ANN based on LMBP algorithm is shown in Table 7. The linear regression between network output and corresponding target is depicted in Figure 3.

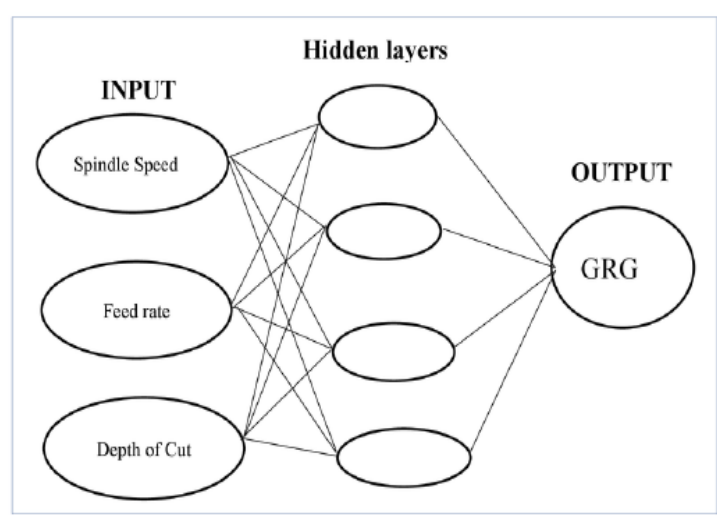

Figure 2. The LMBP Network Topology

Based on the training results from Table 8, the predicted GRGs are nearby \& track almost the similar tendency as of the real GRGs with minimum percentage error. Figure 3 specifies the dashed in individually plot, representing the perfect results - outputs $=$ targets where solid streak indicates the superlative fit linear regression line among outputs and target The correlation among outputs and targets denotes by value of R. For $\mathrm{R}=1$ which displays the linear relationship among the outputs and targets values and for no linear relationship among output and targets for $\mathrm{R}$ is nearby to zero. In this condition training statistics shows a good fit where $\mathrm{R}$ value is greater than 0.9 .

\section{Table 7. Predicted GRGs via well-trained ANN}

\begin{tabular}{|c|c|c|c|c|}
\hline $\begin{array}{c}\text { Exp. } \\
\text { No. }\end{array}$ & Actual GRG & $\begin{array}{c}\text { Predicted GRG } \\
\text { via Trained Network }\end{array}$ & Net Error & Rank \\
\hline 1 & 0.576626954 & 0.576717734828641 & 0.00009 & 8 \\
\hline 2 & 0.457144767 & 0.458127978097685 & 0.00098 & 15 \\
\hline 3 & 0.585281833 & 0.581303088560981 & 0.00398 & 7 \\
\hline 4 & 0.461924366 & 0.454036308194227 & 0.00789 & 14 \\
\hline 5 & 0.568579137 & 0.581286971436704 & 0.01271 & 9 \\
\hline 6 & 0.520293304 & 0.520982829227388 & 0.00069 & 11 \\
\hline 7 & 0.415484858 & 0.428860249455236 & 0.01338 & 16 \\
\hline 8 & 0.557284349 & 0.557390966045230 & 0.00011 & 10 \\
\hline 9 & 0.518473063 & 0.518044534866493 & 0.00043 & 12 \\
\hline 10 & 0.486511004 & 0.485810692059864 & 0.00070 & 13 \\
\hline 11 & 0.62260664 & 0.622842245958913 & 0.00024 & 5 \\
\hline 12 & 0.608643141 & 0.607858428499686 & 0.00078 & 6 \\
\hline 13 & 0.72212744 & 0.708461421973703 & 0.01367 & 1 \\
\hline 14 & 0.671179404 & 0.675050891630410 & 0.00387 & 3 \\
\hline 15 & 0.683992206 & 0.684057140755856 & 0.00006 & 2 \\
\hline 16 & 0.637009917 & 0.637573268320096 & 0.00056 & 4 \\
\hline
\end{tabular}

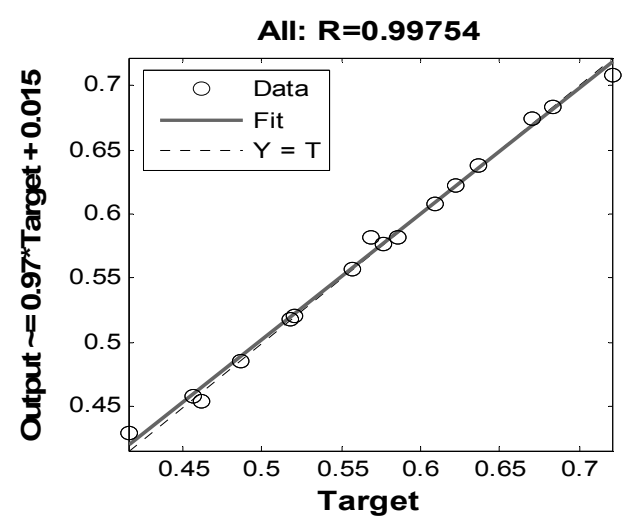

Figure 3. Regression Plot for LMBP Algorithm

\subsection{Simulation via a well-trained ANN}

The optimal parametric setting for Taguchi-based Grey Relational Analysis (A4B1C1) were simulated using a well-trained ANN.The Predicted output (GRG) after the simulation was observed to be 0.76964 . In order to obtain the favorable parametric setting of the turning process, the simulated via well trained ANN was employed where one process parameters was varied into multiple level whereas the others remained constant at the predicted optimum level.

Table 8. Comparative results

\begin{tabular}{|c|c|c|c|c|c|}
\hline \multirow{2}{*}{ Method } & \multicolumn{3}{|c|}{ Optimum parametric setting } & \multirow{2}{*}{ GRG } & $\begin{array}{c}\% \\
\text { Improvement in GRG }\end{array}$ \\
\cline { 2 - 5 } & Spindle Speed (N) & Feed Rate (f) & Depth of cut (d) & 0.72787 & \\
\hline Taguchi-GRA & 860 & 0.06 & 0.6 & 0.76964 & $5.7 \%$ \\
\hline $\begin{array}{c}\text { Taguchi-GRA-ANN } \\
\text { (pred.) }\end{array}$ & 860 & 0.06 & 0.4 & 0.79034 & $8.5 \%$ \\
\hline $\begin{array}{c}\text { Taguchi-GRA-ANN } \\
\text { (optimized parameters) }\end{array}$ & 880 & 0.05 & 0.6 & 0.6 \\
\hline
\end{tabular}




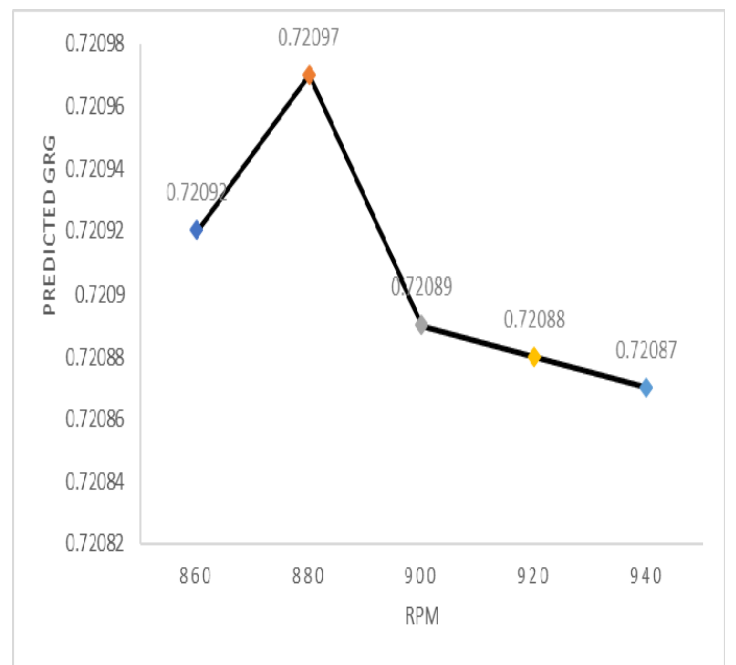

Figure 4. Simulation Results for Multiple Levels of RPM

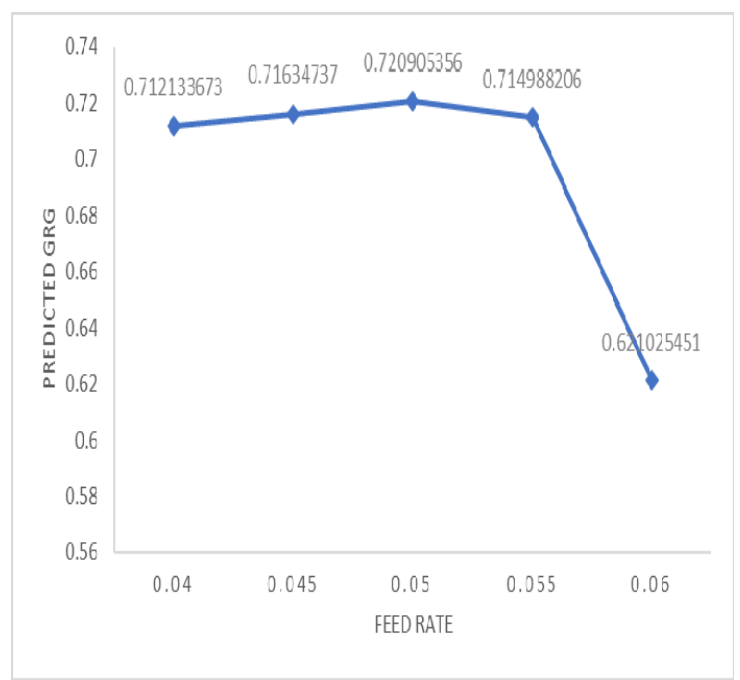

\section{Figure 5. Simulation Results for Multiple Levels of Feed} Rate

The factor A (spindle speed) level was varied from 860 rpm to $940 \mathrm{rpm}$, while the others were kept constant at the predicted optimal level (B1C1). For factor B (Feed rate, $\mathrm{f}$ ), the level was varied from 0.04 to 0.06 , while the others were kept constant at the predicted optimal level (A4C1).

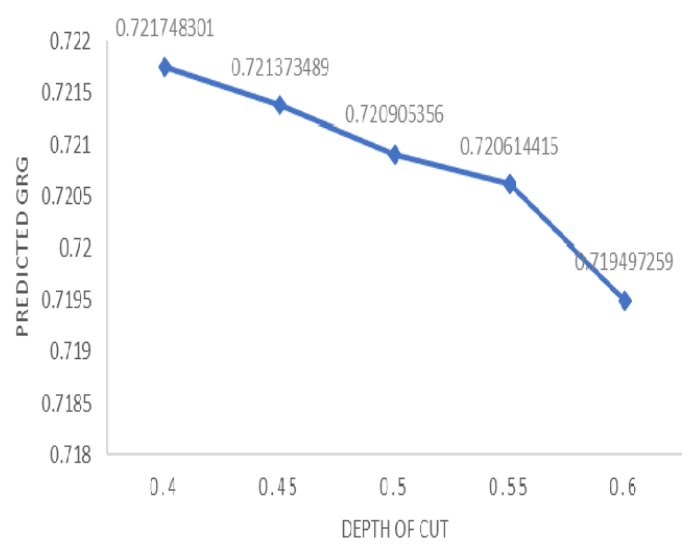

Figure 6. Simulation Results for Multiple Levels of Depth of Cut
Next factor C (Depth of cut, d) level was varied from 0.4 to 0.6 , while the others were kept constant. At the predicted optimum value (A4B1). The simulation results for factor $\mathrm{A}, \mathrm{B}$ and $\mathrm{C}$ upon GRG are depicted in Figure 4, 5 and 6 respectively.

\section{VERIFICATION TESTS}

The verification test has been achieved to recheck the optimal parametric setting predicted by $\mathrm{L}_{16} \mathrm{OA}$ of Taguchi-based GRA with ANN with the actual results. The simulation based on the predicted process parameters via Taguchi-based GRA with ANN was conducted. The result shows that the predicted GRA was 0.79034 . Table 8 shows the experimental results using the optimum process limits predicted via by L16 OA of Taguchi- GRA module and $\mathrm{L}_{16}$ OA of Taguchibased GRA with ANN module.

The predicted GRG of process parameters via $L_{16}$ OA of Taguchi-based GRA with ANN has been improved by $8.5 \%$ which (Table 8 ) shows the satisfactorily performance of aforesaid optimization module. The highest GRG results indicate the desired values of the process responses.

Hence, it has been found that the cutting force, surface roughness and rate of material removal can be simultaneously optimized using a $\mathrm{L}_{16} \mathrm{OA}$ of Taguchi based GRA with ANN. Moreover, the robust optimization can be executed through the assistance of a well-trained ANN, predicting the values outside the specified level of process parameters

\section{CONCLUSIONS}

In this study, a relatively novel module is applied for multi response optmization in Turning of glass fibre reinforced epoxy composites. Grey coupled ANN model has been established towards optimizing Cutting force $\left(F_{r}\right)$, Surface roughness $\left(R_{a}\right)$ and rate Material Removal Rate (MRR) were transformed into a single multiperformance characteristic function known as GRG. By this technique, a multi-attribute optimization case has been altered to an equivalent single objective function which has been finally resolved by Taguchi module.

1. The simulation via well-trained ANN predicted that Spindle speed (880 RPM), Feed rate $(0.05 \mathrm{~mm} / \mathrm{rev})$ and depth of cut $(0.4 \mathrm{~mm})$ produce the highest GRG which has been verified by confirmatory test shows the feasibility of this module.

2. The predicted GRG of process parameters via L16 OA of Taguchi-based GRA with ANN has been improved by $8.5 \%$ which shows the satisfactorily performance of aforesaid optimization module.

3. The proposed optimization module is operative in evolving a strong, adaptable and flexible mass manufacturing technique. GRA coupled ANN model can resourcefully take care of multi criteria variables into its fundamental grading thereby overcoming the restriction of prevailing Taguchi based optimization approaches. This method can be endorsed for con- 
stant quality enhancement and off-line quality regulator of engineering process/product.

4. Parameters related to material properties like matrix to fibre ratio, fibre orientation etc. can be considered as process parameters in future scope and Interface outcome of process constraints can be explored in detail, beside this, effects of varying tool material and tool geometry on machining performance of GFRPs can be examined in future for grinding, shaping, milling, etc.

\section{REFERENCES}

[1] Uhlman, E., Sammler, F., Richarz, S., Recucher, G., Hufschimed, R., Frank, A., Statwiszynski, and Protz, F.: Machining of Carbon and Glass Fibre Reinforced Composites, Procedia CIRP, Vol. 46, pp. 63-66,2016.

[2] Zitoune R., Collombet F., Lachaud F., Piquet R., Pasquet P., Experiment - calculation comparison of the cutting conditions representative of the long fiber composite drilling phase, Composites Science and Technology, Vol. 65 pp. 455-466,2005.

[3] Verma, R. K, Abhishek, K., Datta, S. and Mahapatra, S. S., Fuzzy rule-based optimization in machining of FRP composites, Turkish Journal of Fuzzy Systems, Vol.2 issue 2, pp. 99-121,2011.

[4] Khan, M.A., Kumar, A.S., and Poomari, A., A hybrid algorithm to optimize cutting parameter for machining GFRP composite using alumina cutting tools,International journal of. Advance Manufacturing and Technology, Vol. 59, no. 9-12, pp. 1047-1056,2012.

[5] Kumar,S.S,Ashok,S.D.,and Narayan,S., :Investigation of friction Stir Butt welded Aluminium Alloy Flat Plates Using Spindle Motor Current Monitoring Method, Procedia Engineering; Vol.64: pp.915-925,2013.

[6] Ramulu, M.: Machining and surface integrity of fibre-reinforced plastic composites, Sadhana, vol. 22, issue 3, pp. 449-472,1997.

[7] Agrawal, D.P., and Kamble D.N., GRA and ANN Integrated Approach for Photochemical Machining of $\mathrm{Al} / \mathrm{SiC}$ Composite, Materials Today: Proceedings, Vol. 4, Issue 8 pp. 7177-7188,2017

[8] Lakshminarayanana, K., and Balasubramanian, V, :Process parameters optimization for friction stir welding of RDE-40 aluminum alloy using Taguchi technique, Transactions of Nonferrous Metals Society of China ; vol.18 issue 3,pp.548-554.2008

[9] Gopal, P.M., and Prakash. K.S., Minimization of cutting force, temperature and surface roughness through GRA, TOPSIS and Taguchi techniques in end milling of $\mathrm{Mg}$ hybrid MMC,Measurement Vol. 116 pp. $178-192,2018$

[10] Lakshminarayan,andA.K.,Balasubramanian,V.:Co mparison of RSM with ANN in predicting tensile strength of friction stir welded AA7039 aluminum alloy joints, Transaction of Nonferrous Metals Society of China ,Vol. 19, Issue 1,pp. 9-18,2009
[11]Basheer,A. C.,Dabade U. A.,Joshi, S. S.,Bhanuprasad, V. V., and Gardre,V. M.:Modeling of surface roughness in precision machining of metal matrix composites using ANN,Journal of Material and Processing Technology, vol. 197, no. 1-3, pp. 439-444,2008.

[12] Verma, R.K., Kumar A, Datta S, Pal PK and Mahapatra, S.S, Multi-Response Optimization in Machining of GFRP (Epoxy) Composites: An Integrated Approach, Journal of Manufacturing Science and Production; Vol.15, no.3, pp. 267-292, 2015.

[13] Ezugwu, E.O., Fadare, D.A., Bonney, J., Da Silva, R.B. and Sales, W.F.: Modelling the correlation between cutting and process parameters in highspeed machining of Inconel 718 alloy using an artificial neural network, International Journal of Machine Tools and Manufacture, Vol. 45, No. 1213, pp. 1375-1385, 2005.

[14]Hans Raj, K., Sharma, R.S., Srivastava, S. and Patvardhan, C.: Modeling of manufacturing processes with ANNs for intelligent manufacturing, International Journal of Machine Tools and Manufacture, Vol. 40, No. 6, pp. 851-868, 2000.

[15]Zain, A.M., Haron, H. and Sharif, S.: Prediction of surface roughness in the end milling machining using artificial neural network, Expert Systems with Applications, Vol. 37, No. 2, pp. 1755-1768, 2010.

\section{ГРЕЈОВА РЕЛАЦИОНА АНАЛИЗА УГРАБЕНА У ВЕШТАЧКУ НЕУРОНСКУ МРЕЖУ БАЗИРАНА НА ПРИСТУПУ ХИБРИДНЕ ОПТИМИЗАЦИЈЕ МАШИНСКЕ ОБРАДЕ СТАКЛЕНИМ ВЛАКНИМА ОЈАЧАНИХ ЕПОКСИ ПОЛИМЕРНИХ КОМПОЗИТА}

\section{П.К. Карвар, Р.К. Верма}

Епокси полимерни композити ојачани стакленим влакнима (GFRP) се налазе у средишту интересовања због својих изузетних техничких својстава као што је врло добар однос чврстоће и тежине, као и побољшани век трајања. Међутим, развијање машинске компоненте је отежано због нехомогености и анизотропног понашања GFRP композита. У овом раду који приказује хибридни модул у вештачку неуронску мрежу уграђена је Грејова релациона анализа базирана на Тагучијевом приступу вишекритеријумске оптимизације код машинске обраде GFRP композита. Постављене карактеристике обраде су минимална сила резања, минимална храпавост површине и максимална брзина уклањања материјала. За сваки фактор је одређен одзив приликом израчунавања Грејовог релационог коефицијента, а затим је сваки преведен у појединачну одзивну функцију, тј, вредност Грејовог степена релације (GRG). GRG је узет за превођење проблема више циљева у проблем једног циља да би потом добро утренирана вештачка неуронска мрежа базирана на LMPG алгоритму била 
искоришћена за предикцију најповољнијих параметара процеса, тј. брзину вретена (880rpm), брзину помоћног кретања $(0,05 \mathrm{~mm} / \mathrm{rev})$, дубину резања $(0,4 \mathrm{~mm})$. Предвиђени GRG процесних параметара преко $\mathrm{L}_{16} \mathrm{OA}$ Грејове релационе анализе базиране на Тагучијевом приступу са вештаком неуронском мрежом побољшан је за 8,5\%. Оваква поставка експеримента је одабрана на основу највишег GRG предвићеног вештачком неуронском мрежом, а што је на крају проверено конфирмационим испитивањем које је дало задовољавајуће резултате. 